\title{
Elite Integration and Institutional Trust in Norway
}

Published in Comparative Sociology 6 (2007) 190-214

Trygve Gulbrandsen, Universitetet i Oslo

t.j..gulbrandsen@sosiologi.uio.no

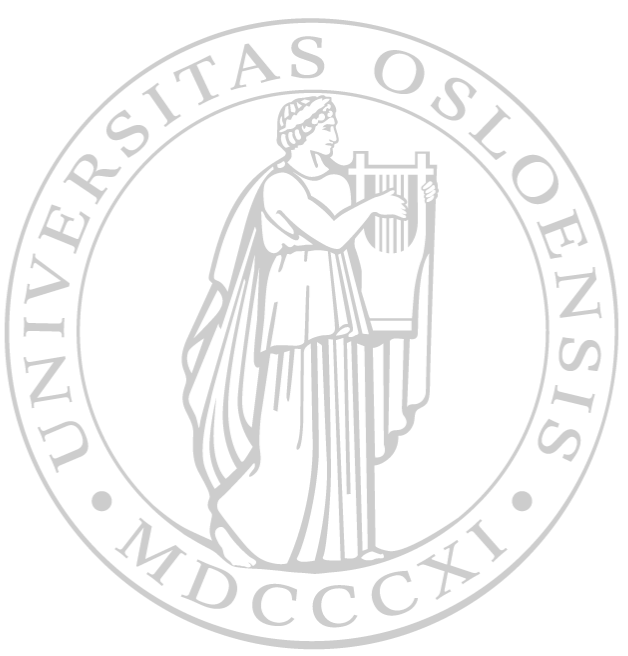

Department of Sociology \& Human Geography University of Oslo

P. O. Box 1096 Blindern N-0317 OSLO Norway

Telephone: $\quad+4722855257$

Fax:

$+4722855253$

Internet: http://www.iss.uio.no/ 


\title{
Elite Integration and Institutional Trust in Norway
}

\author{
Trygve Gulbrandsen \\ Institute for Social Research, Oslo, Norway, and \\ Department of Sociology and Human Geography, University of Oslo, Norway \\ trygve.gulbrandsen@socialresearch.no
}

\begin{abstract}
In modern elite theory accommodation and compromise between national elite groups are seen as preconditions for the continuance and stability of a democratic society. It is claimed that elite accommodation is facilitated to the extent that the elites are integrated. In this article trust between the various elite groups and their respective institutions is investigated as a core aspect of elite integration. The analyses presented in the article demonstrate that in general there is a relatively high level of institutional trust among national elite groups in Norway. There is, however, some variation in how much trust the various elite groups accord the institutions to which other elite groups belong, and this is explained by (1) the extent to which one elite identifies with the functions of other elites, (2) has a similar ideological orientation, and (3) has social contact with members of other elites.
\end{abstract}

\section{Keywords}

elites, elite integration, institutional trust

\section{Introduction}

The traditional elite theorists - Pareto, Mosca and Michels - contended that in any society there will be distinction between an elite of leaders and the masses, the led. As Higley and Burton (2006) have demonstrated, these theorists did not, however, claim that the elite always and everywhere will be unitary. On the contrary, Mosca (1939), for instance, stressed the variability of elite organization, cohesion and collective will.

Some decades later scholars within the "power elite" tradition (Mills 1956; Porter 1965) maintained that the private and public elites in USA 
and Canada were integrated to an extent that they constituted a single ruling group in society - a power elite. According to Mills (1956), the economic, political and military elites in USA were integrated through common class background and education and through family ties and belonging to the same social networks.

This research spurred an increased interest in studying whether national elites or particular sector elites are cohesive and integrated or, alternatively, whether they are fragmented (Domhoff 1967; Putnam 1976; HoffmanLange 1985; Higley et al. 1991; Kadushin 1995; Bürklin and Rebenstorf 1997).

In contrast to the "power elite" theory, in more recent elite theory (Lijphart 1969a, 1969b; Presthus 1973; Putnam 1976; Higley and Burton 1989) elites are rather described as institutionally distinct, socially disparate and politically diverse groups of national leaders. Mutual accommodation, compromises and consensus between these elite groups are seen as preconditions for the continuance and stability of democracies. In such a context "traditional" mechanisms of elite integration, as the ones focussed upon by Mills (1959), are less significant.

In my analysis, using the same framework, elites are defined as the holders of top positions in central institutions and organizations within significant sectors of the Norwegian society, for instance the political system, the economy and cultural life. As holders of leadership positions these elites act as representatives of the interests and concerns embodied in the particular institutions or organizations. They have been delegated power to act on behalf of and are responsible to the principals of the individual institutions. Members of parliament are for instance responsible to the voters, senior civil servants to the elected politicians, union leaders to the union members, and private business leaders to the shareholders. Through processes of selection and socialisation the institutions and their principals see to that the persons entering the top leader positions are familiar with and have internalised the values and interests which the institutions are embodying.

Because the institutions stand for different concerns and interests, the various elite groups are prevented from automatically converging into one single ruling group.

Under these circumstances some extent of elite integration is a prerequisite for arriving at accommodation and compromise between the institutionally 
disparate elites. It becomes important then to focus upon those aspects of elite cohesion which motivate elites to enter into and stick to compromises with other elite groups.

Following Higley and Moore (1981), I argue in this paper that trust is a core aspect of elite integration. In line with this argument I examine to what extent the different elite groups in the Norwegian society have confidence in each other's institutions.

In an earlier article, Gulbrandsen (2005a) focussed on the overall trust of the national elites in the most important private and public institutions in Norway. This study documented that many of the institutions receive relatively high trust by the elites.

Any high overall trust, indicating that the elites are integrated, may however, conceal situations where particular elite groups have low trust in significant institutions. Instances of low institutional trust on the part of particular elite groups can create social tension and undermine the possibility for compromise and national elite accommodation. Consequently, it is necessary to examine the structure of the trust relations between individual elite groups and institutions. In this paper, therefore, an examination is made of the extent to which variations are found in the trust which the members of the various elite groups accord the institutions concerned together with an attempt to explain any variations observed.

Three factors or circumstances are discussed which may explain variations in institutional trust and accordingly in the extent of elite integration along this dimension: (1) the institutional affiliation of the top leaders and the significance of the basic functions and interests of the institution or sector for their orientations and actions, (2) the leaders' own ideological attitudes, (3) the extent of personal contact or interaction with top leaders in other institutions and sectors.

The hypotheses developed in this discussion are subsequently analysed empirically with the aid of data from a large and unique survey study of a sample of Norwegian economic, political and social elites, the Norwegian Leadership Study, undertaken in 2000. This study was an important part of the Power and Democracy Project, a five year project commissioned by the Norwegian parliament. The Leadership Study was conducted by Institute for Social Research in collaboration with Statistics Norway. 


\section{The Case of Norway}

Norway is an interesting case for three reasons. First, it is a high trust society. A recent study has demonstrated that Norway ranks highest in the world as to interpersonal or social trust (Delhey and Newton 2005). The high trust level is related to Norway's Protestant tradition and ethnic homogeneity as well as good government, wealth and income equality. The citizens' trust in the political institutions has traditionally also been quite high. Their trust in politicians is, however, approaching a rather low level, although this has been normal in many other industrial countries for some time (Strømsnes 2003).

Secondly, Norway is a stable democracy with roots back to the early nineteenth century. With the 1814 Constitution Norway acquired one of the most democratic systems in Europe. It is a society with striking egalitarianism, a strong public sector and an advanced welfare system. Moreover, there has been a widespread consensus on basic properties and norms of the Norwegian democracy. The consensus has grown out of previous class compromises, and compromises between opposing interest groups. The compromises were forged between the leaders of the various class and interest organisations or movements. In that sense, these compromises were elite compromises.

The elite compromises have a two-tier structure (Gulbrandsen et al. 2002). A compromise of the first order is tied to the constitution, the emergence of parliamentarianism and the gradual accommodation of popular movements into the polity. This culture of responsiveness by the elites is still basically intact. Compromises of the second order comprise the centralized system of wage negotiations and relative egalitarianism, the inclusion of women in the wage market and public affairs, the regional policy of redistribution, and the conduct of defence and foreign policy.

Thirdly, Norway has a particular variety of capitalism which partly explains Norway's egalitarian and popular state policies and its universalistic welfare system. Historically, the Norwegian economy lacked large, dominating firms in production and credit supply and the bourgeoisie has been weak, characterized by many small and medium-sized enterprises. In spite of a liberal orientation the State had to step in to safeguard the emerging industries, investing heavily in the infrastructure and assisting the establishment of a national banking system. The State had thus to compensate for the absence of an 'organized capitalism' and became a senior 
partner to private business. This model has been characterized by a leading historian as "democratic capitalism" (Sejersted 1993), a state dominated capitalism tempered by small-scale enterprises and strong norms of popular legitimation.

These particular features of Norwegian society make Norway an interesting case concerning integration and institutional trust within the national elite. The high-trust culture can be expected to give a fertile ground also for the elites' trust in each other's institutions. This trust has probably been strengthened by the widespread elite consensus and elite compromises. Also, the long tradition of public involvement in business may have fostered trust in the political institutions even among elite groups usually sceptical toward the State.

\section{Theory and Hypotheses}

\section{Elite Integration}

In general, integration means that different elements are combined into a whole, that a kind of unity is created among the elements. Elite integration thus implies that the different elites are unified in one way or another. This unity is manifested in various ways: (1) as consensus on significant values or on the desired properties of the society, (2) as subjective feelings or perceptions of belonging to the same community, (3) as perceptions across different elite groups of being complementary, i.e. that they are mutually dependent upon each other, (4) through instances of collective action and cooperation.

I suggest that widespread trust in the main institutions of a society is a significant characteristic of elite unity. Institutional trust is a vital expression of both of an awareness of community and of complementarity.

Elite integration then has many dimensions, implying that a particular set of elites may be integrated along one dimension, but not necessarily along another. For instance, national elites can be integrated through institutional trust and general support for the democratic institutions and rules of the game, but at the same disagree about the size and scope of the welfare state; or they are integrated through an extensive network of contacts and interaction, but still oppose each other on important ideological issues. It is difficult to specify concrete criteria for determining whether national 
elites or subsections of a particular elite group are integrated or not. Elite integration is a rather continuous (and composite) variable, i.e. the national elites are more or less integrated or united along the different dimensions.

\section{Institutional Trust}

In an early analysis Deutsch (1962) defined trust giving as acts which increase a person's vulnerability to another person at the same time as the behaviour of this second person cannot be controlled by the first one. According to Baier (1986) trust is present when a person accepts to be vulnerable to another person's potential but not expected lack of good will. Offe (1999) maintains that we have trust when we believe that another person will increase our welfare or abstain from hurting us. These definitions illustrate that within the theoretical literature on trust there is a distinction between those contributions viewing trust as first and foremost concrete acts and those focussing upon trust as beliefs or attitudes.

I define trust as an attitude on the part of one individual towards another individual, or towards an institution or a social system concerning the future behaviour of the other or the future outcome of relating to the particular institution. It involves an expectation that the other individual or the institution will execute or abstain from certain actions at a certain point of time in the near or distant future. One characteristic of situations where such an attitude emerges is that the trust-giver has no control of the future actions of the other part: there is a risk that the other's behaviour will fall short of the trust-giver's expectations. Another characteristic is that the trust-giver will suffer a noticeable loss if his or her expectations concerning the behaviour of the other part are not met.

Since the elites relate to each other as representatives of particular institutions, their trust in each other is as much a trust in their respective institutions. Institutional trust embodies the belief that institutions have established mechanisms for guaranteeing that actions taken by their representatives are binding for the institution as such. In this way institutional trust provides a basis for having trust in the promises made by the representatives of the individual institutions.

Institutional trust bears witness to a perception on the part of the various elite groups of national unity and a support for the basic institutions of society. This awareness of unity stimulates cooperation and compromise between the different elites and helps them concert their actions to the 
benefit of all, the effects of which are to reinforce the integration of the national elites.

There are, however, reasons to believe that there are variations as to how much trust the various elite groups accord the individual institutions. On the level of the individual members of the elite groups there are three main sources of such variations:

(1) As emphasized above, the orientations and actions of the top leaders in the Norwegian society are affected by, and reflect the institutions or sectors which they represent. I suggest that the institutional affiliation of the elite persons also influences how they consider the trustworthiness of other institutions.

Social psychological belief-congruency theory (Rokeach et al.1960) claims that there is a natural tendency for people to associate with and be more comfortable with others having similar belief systems. Similar groups are assessed more favourably than dissimilar ones. This theory has been developed for explaining the prejudice and stereotype majorities hold about minorities. Delhey and Newton (2005) argue that this theory can be transferred to social trust: the greater the perceived similarity of other people, the more they are trusted. Similarly, I suggest that one mechanism through which institutional affiliation may affect the top leaders' institutional trust is identification. Identification implies an association of feeling or interest with another person or a group. Top leaders who work in institutions with similar basic functions will have a particular understanding for each other's responsibilities, which may promote a mutual identification between the involved leaders. Without personal experiences from a particular institution or with its representatives identifying with it/them nonetheless stimulates a feeling of familiarity which in itself may foster trust in the institution concerned.

I distinguish between four types of elite groups according to the basic function of their institution: (i) Social order elites, i.e. the military elite, top leaders within the police and the judges in the courts of justice and top leaders within the church; (ii) Intellectual elites, comprising the academic elite, the cultural elite and leading persons within the mass media; (iii) Political elites covering members of parliament, leaders of political parties, members of the cabinet, political leaders in the largest municipalities, and top leaders in state bureaucracy; (iv) Production elites, including top lead- 
ers within private business, public (state) business enterprises and within the cooperative sector.

I expect the trust between elite groups representing institutions with similar basic functions to be higher than between elite groups which have different functions, i.e. such trust relations are to be expected within each of the groups of "social order", "intellectual", "political", and "production" elites/institutions respectively. As an example, I expect that top leaders in the military services and the judges and top leaders within the police have more trust in each other's institutions than in other elite groups.

But the responsibilities of the members of a particular elite group may also bring them in opposition to other institutions or to foster distrust in them. One example is the mass media elite. Mass media feel responsible for monitoring what is going on in the other institutions in society. They watch and report any abuse of the power which leaders in these institutions hold. This task instils into the members of the mass media elite a critical attitude towards society which may breed institutional distrust.

(2) It is reasonable to assume that the top leaders' ideological beliefs influence the level of trust in the main institutions of society, independent of their institutional affiliation. ${ }^{1}$ For many individuals ideology is an important cognitive aid when attempting to orient themselves in a complex world. The same is probably valid for top leaders as well. By attaching labels of positive or negative value to particular institutions ideological beliefs then influence the top leaders' cognitive/emotional process of trust giving.

The ideological controversies in Norwegian history, and up to the present day, have particularly gravitated around the size and role of the state. The structure of the political parties in Norway has to large extent developed around the private/public issue. Moreover, citizens' attitudes towards this private/public cleavage have significantly influenced how their votes have been cast in elections (Aardal 2003).

The Norwegian welfare state model is supported by a majority of the political parties and the members of the Norwegian parliament ("the Storting”). I therefore assume that elite groups whose members largely oppose this model "translate" their ideological dissatisfaction into lower trust in the political institutions. Among the Norwegian elites the top leaders within

\footnotetext{
1) Studies of ordinary citizens have demonstrated that their institutional trust is significantly related to their ideological orientation (Listhaug and Wiberg 1995).
} 
private business are the strongest opponents against the present authority and responsibilities of the state (Gulbrandsen 2005b). Accordingly, it is to be expected that the private business elite will appear with distinctly lower trust in the political institutions than the other elite groups. Conversely, I expect that elite groups which ideologically have much sympathy for the present welfare state model have relatively high trust in political institutions.

(3) According to general theories about trust (Blau 1964; Coleman 1990), this gradually evolves and is extended the more frequently two individuals or partners see each other, and the longer their relationship lasts. In line with these ideas it is to be expected that a top leader's trust in a particular institution will depend upon how much contact he or she has with the top leaders representing that institution.

Accordingly, I expect to find that members of elite groups with frequent contacts with the top leaders in an institution will have more trust in the institution concerned than elite groups with less contact. An example of frequent contacts between two elite groups is the relationship between top leaders in the state administration and politicians in the Cabinet and the Storting. It is to be expected that politicians and senior public officials will also have a high degree of trust in each other's institutions.

\section{Data and Method}

In the Leadership Study the sample of top leaders was constructed on the basis of a so-called "position" method., i.e. we included those persons who occupy the most important leadership positions in twelve sectors of Norwegian society. ${ }^{2}$ Personal interviews were held with 1710 top leaders, 87.3 per cent of those who were approached for an interview.

In the Leadership Study institutional trust was enquired into in the following manner: "How much trust do you have in the institutions listed on this card. Please rank the institutions on a scale from 0 to 10 , where 0 is no trust and 10 is very high trust." ${ }^{3}$ In this article the focus is upon the elites'

2) (1) The church, (2) the State administration, (3) culture, (4) mass media, (5) private business, (6) cooperative enterprises, (7) public business enterprises, (8) organizations, (9) universities and research institutes, (10) police and the judicial system, (11) military services, and (12) politicians, i.e. members of the Storting, leaders of the political parties and members of the Cabinet and their political secretaries.

3) The chosen formulation of the trust question covers the leaders' generalized or diffuse 
trust in the following 13 institutions: (1) the Cabinet, (2) the political parties, (3) the Storting, (4) the courts of law, (5) the public administration, (6) the police, (7) the mass media, (8) the church and the religious organizations, (9) the trade unions, (10) private business, (11) voluntary organizations, (12) universities and research institutes, (13) the military services. Figure 1 aggregates the trust of each of the twelve elite groups in all the thirteen institutions. ${ }^{4}$

As indicator of the leaders' ideological orientation it is used a "public/ private" index including questions measuring the extent to which the individual leaders endorse some main properties of the welfare state model. ${ }^{5}$

The leaders' contacts with other top leaders in society were charted enquiring how frequently during the last year they had been in contact with a member of the various elite groups. ${ }^{6}$

As control variables in the analyses I have used (i) Education, a variable with 8 values according to educational level, (ii) Age as a continuous variable, and (iii) Gender.

In order to test the hypotheses about which factors and circumstances influence the variations in the elites' institutional trust it was carried out

trust. The replies we have received must be seen as an aggregated or condensed judgment which may be founded upon several different experiences, impressions and views held by the leaders. A particular top leader may have a trust or distrust for several different reasons. Accordingly, there may be some variation between different leaders in the emphasis expressed in their judgment. We know nothing, however, about the individual reasons for this.

4) The information about the top leaders' trust in their own institutions was taken out.

5) We asked the leaders whether they agreed with the following four statements: (1) "It is more important to extend public services than to reduce taxes"; (2) "In Norway one should put stronger emphasis upon privatisation and a smaller public sector"; (3) "The state influence on private business should be reduced"; (4) "In Norway we have gone far enough in the reduction of income inequalities". The answers were coded similarly. The index is based upon the mean of the leaders' evaluation of the four statements and has values from 1 to 4 . The value 4 indicates that the leaders fully back the public sector and policies for levelling incomes. The value 1 indicates that the leaders favour a smaller public sector, more privatisation and a curtailing of the state power over private business. Cronbach's alpha for the index is 0.83 .

6) A contact variable for each elite group was constructed, each with four values: "weekly or more frequently" (4), "monthly", (3) "less frequently" (2) and "never" (1). In the models the variables were used as continuous variables. In the Leadership Study top leaders within the state administration were not asked about their contacts with the members of the Cabinet and the Storting. 
a series of statistical analyses relating the individual top leaders trust in each of ten selected institutions to the explanatory and control variables, cf. Tables 2 and 3.

\section{Results}

\section{The Leaders' Trust in the Institutions of Society}

Figure 1 presents the mean trust scores across all the thirteen institutions for each of the twelve elite groups, what we may term the general institutional trust of the elite groups. The figure demonstrates that in general there is a relatively high level of institutional trust among the national elite groups in Norway. Given the particular trust fostering features of the Norwegian society described above, I had expected, however, that the level of institutional trust was somewhat higher. The differences between the various elite groups as to general institutional trust are small. None of the elite groups stand out from the other elite groups neither as to high nor low trust, in itself an indication of an extensive degree of integration among the elites in Norway.

To explore the interrelations between the various elite groups and their respective institutions table 1 shows each elite group's average trust in each of the thirteen institutions. The patterns which emerge in the table support several of the empirical expectations which were formulated above.

As expected, the top leaders in the state administration constitute the elite group which has the highest trust in the political institutions - the Storting (6.8), the Cabinet (7.6) and the political parties (5.1). Their trust in the Cabinet is higher than what any other elite group has reported. This finding may be a result of what I described above as "identification". They may identify with the basic responsibilities of the politicians in the Cabinet, and this identification may in itself foster trust. Another possibility is that the top leaders reported high trust in the Cabinet because they had ideological sympathy with the political party which at the time of the

7) In each of these analyses I excluded those leader groups which are closely connected to the institutions concerned, i.e. (1) and (2) politicians and senior public officials, (3) politicians, (4) senior public officials, (5) leaders in the police and the judicial system, (6) higher military officers, (7) leaders in the church, (8) top leaders in private business, and (9) national leaders in the trade unions. 


\section{Figure 1}

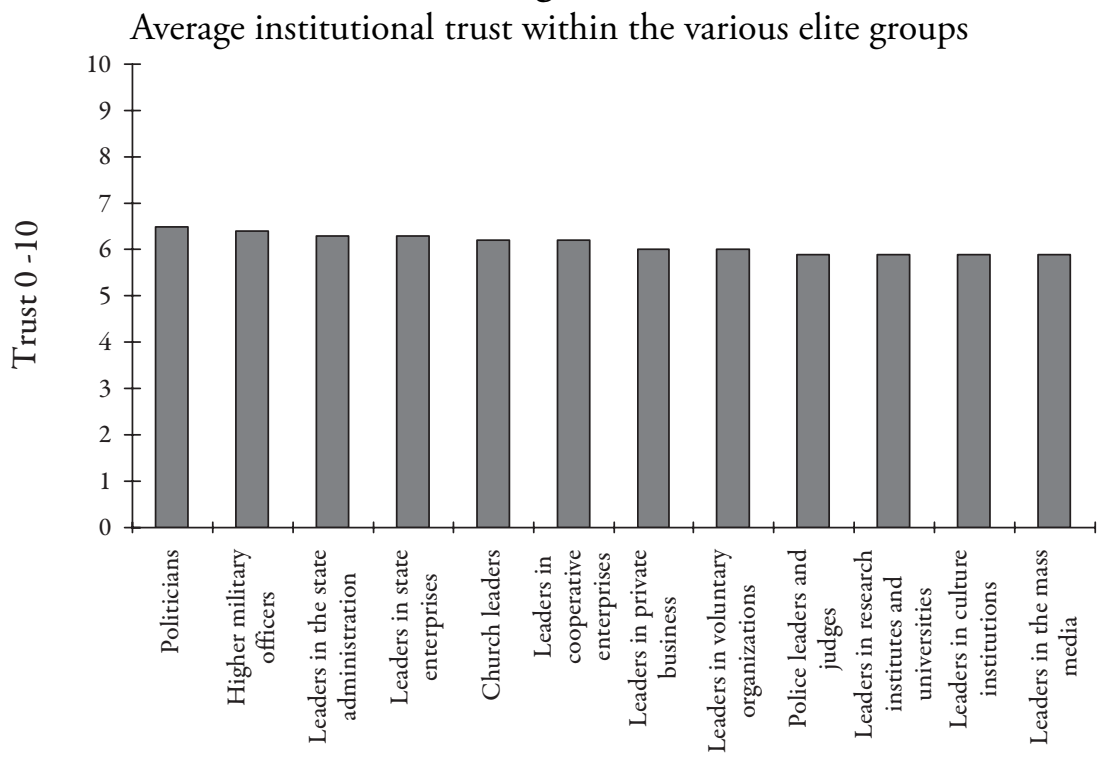

Elite groups

interviews occupied the Cabinet - the Labour Party. But the finding may also be an indication of the relevance of the idea that frequent contact with a specific institution promotes higher trust in that institution. Finally, the initiatives and decisions taken by the Cabinet are usually based upon advice given by the civil service itself. The trust that the top leaders in the administration gives to the Cabinet is then as much a trust in their own work.

Below, I study the relative significance of the various theories more thoroughly through multivariate statistical analyses of the trust attitudes of the individual top leaders.

For their part the politicians reciprocate the trust received by the senior public officials by giving the state administration relatively high trust (6.4), second only to the level of trust given by judges and top leaders within the police (6.9).

Also, as expected, the order institutions constitute a cluster of institutions characterized by high mutual trust. The top officers in the military services accord the courts of justice and the police high trust (8.3 and 7.9 


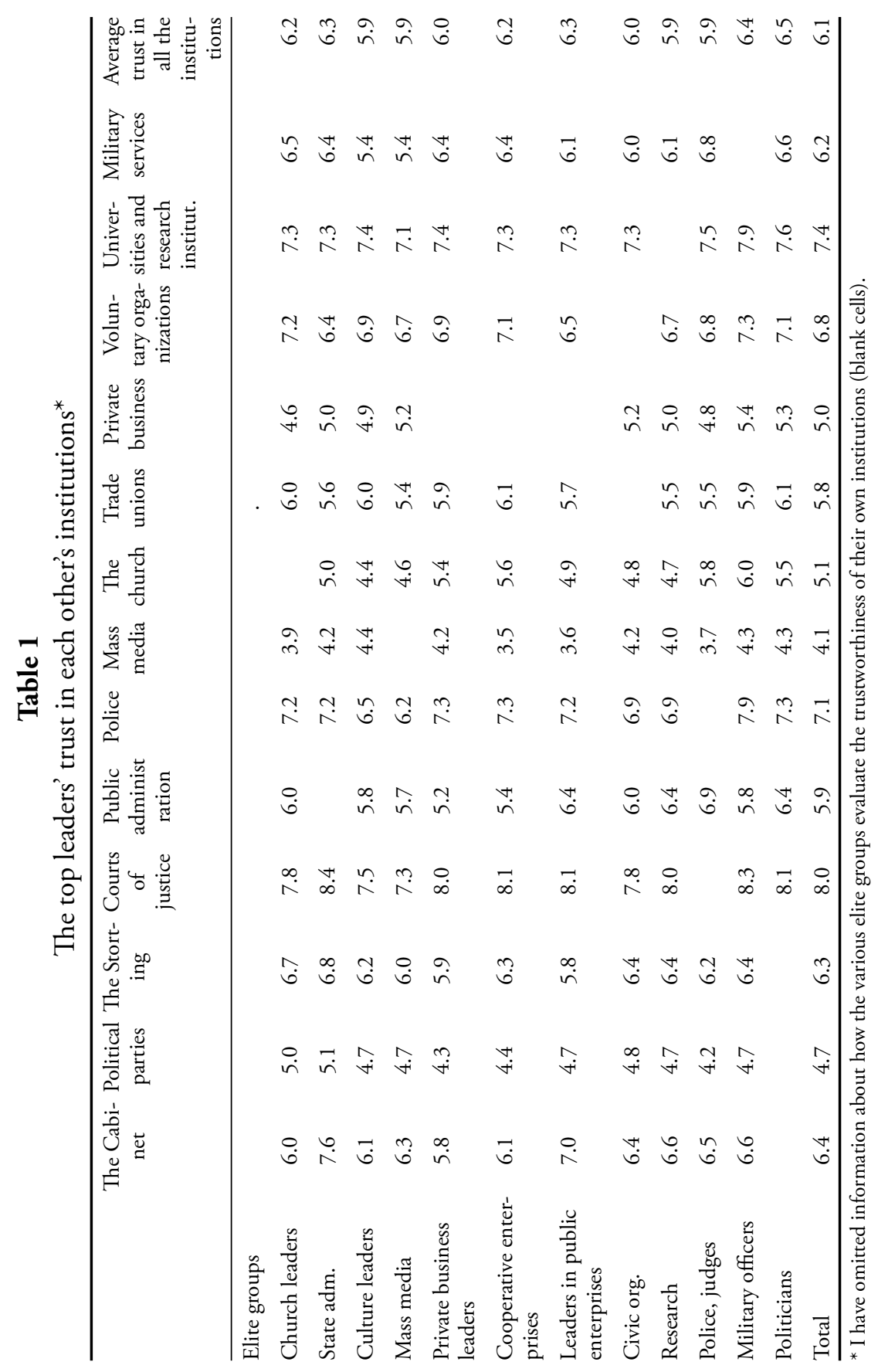


respectively), while the leaders within the police and the group of judges on their part give more trust to the military services than any other elite groups (6.8). This pattern of high mutual trust between the members of the elite groups connected to the two order institutions is an indication of the significance of the process of "functional" identification for the development of institutional trust.

Above, I suggested that top leaders within the mass media may be particularly critical of the other institutions. Table 1 lends support to this idea. The table demonstrates that the mass media elite, but also the top leaders within the culture sector have in fact lower trust in the order institutions (the courts of justice, the military services and the police) and the church, than any of the other elite groups. The members of the two intellectual elites then seem to be less willing than other top leaders to accept the reasons for legitimacy traditionally pleaded by the order institutions and the church.

As expected, the members of the private business elite express reservations towards the political institutions. Not surprisingly, private business leaders have lower trust in the Cabinet and public administration than any other elite group, and second lowest trust in the Storting and the political parties. The differences to the other elite groups are, however, relatively small. In line with the discussion above this trust pattern may be related to the ideological beliefs of the private business leaders. Ideologically, the top leaders within private business are strongly in favour of reducing the size and responsibilities of the public sector and of allowing larger income inequalities. Below I will examine whether their relative low trust in the political institutions is a reflection of these ideas.

Table 1 shows that the church leaders have lower trust in private business than any other elite groups. Gulbrandsen et al. (2002) found that the church leaders ideologically represent a counterpart to the private business leaders. It is probable that this state of affairs influences church leaders to place low confidence in private business. On the other hand the private business leaders' trust in the church is on a par with the other elite groups.

Table 1 reveals that the mass media receives much less trust from the other elite groups (on average 4.1) than leaders in the mass media on average give the other institutions in the society (5.9). In empirical studies of trust relations between individual citizens it has been found that individuals who are met with low trust react by reducing their own trust in other 
persons. It is noticeable that this social psychological mechanism does not seem to be operative among the top leaders in the mass media. In spite of the low trust they receive from the other elite groups, they continue to have a general institutional trust on a level similar to these groups. The leaders within the mass media are probably well aware of the costs of their role as watchdogs in the society and accept that low trust is the price they have to pay for meeting the requirements of this role.

\section{Factors Explaining the Variations in the Elite Groups' Institutional Trust}

Table 1 demonstrates that there are distinct variations between the elite groups as to how much trust they accord each of the other institutions. Moreover, the findings also seem to lend support to the hypotheses discussed in the theoretical section above. The simple descriptive analysis in Table 1 is not sufficient however for confirming or refuting the hypotheses. A more satisfactory statistical basis for determining the relative merit of the three explanations of the variations in the elites institutional trust is presented in Tables 2 and 3. These tables present the results of regression analyses where the variations in the individual top leaders' trust in each of ten of the institutions are related to the three explanatory variables.

\section{Table 2}

The individual top leaders' trust in political institutions. Regression analyses (OLS). Non-standardized estimates

\begin{tabular}{|c|c|c|c|c|}
\hline & $\begin{array}{l}\text { Trust in the } \\
\text { Storting }\end{array}$ & $\begin{array}{l}\text { Trust in the } \\
\text { cabinet }\end{array}$ & $\begin{array}{l}\text { Trust in } \\
\text { the public } \\
\text { administration }\end{array}$ & $\begin{array}{l}\text { Trust in } \\
\text { the political } \\
\text { parties }\end{array}$ \\
\hline Intercept & $4.839^{* *}$ & $4.549^{* *}$ & $5.23^{* *}$ & $3.609^{* *}$ \\
\hline $\begin{array}{l}\text { Ideological } \\
\text { orientation: the } \\
\text { private/public cleavage }\end{array}$ & $0.325^{* *}$ & $0.374^{* *}$ & $0.381^{* *}$ & $0.368^{* *}$ \\
\hline $\begin{array}{l}\text { Contact with leaders in } \\
\text { the respective } \\
\text { institutions }\end{array}$ & $0.149^{*}$ & $0.225^{* *}$ & $0.223^{* *}$ & $0.167^{* *}$ \\
\hline
\end{tabular}


Table 2 (cont.)

$\begin{array}{llll}\begin{array}{l}\text { Trust in the } \\ \text { Storting }\end{array} & \begin{array}{l}\text { Trust in the } \\ \text { cabinet }\end{array} & \begin{array}{l}\text { Trust in } \\ \text { the public } \\ \text { administration }\end{array} & \begin{array}{l}\text { Trust in } \\ \text { the political }\end{array} \\ \end{array}$

Elite group (reference

group: private

business leaders):

Leaders in the

0.406

$-0.241$

0.090

0.286

Church

Leaders in the state

$0.686^{* *}$

$1.135^{* *}$

$0.474^{* *}$ admin.

Leaders in culture

$-0.068$

$-0.095$

0.177

institutions

Leaders in mass

$-0.227$

0.079

$-0.305$

media

Leaders in

\begin{tabular}{lcccc}
$\begin{array}{l}\text { cooperative } \\
\text { enterprises }\end{array}$ & 0.246 & 0.0005 & 0.001 & -0.197 \\
$\begin{array}{l}\text { Leaders in public } \\
\text { enterprises }\end{array}$ & -0.284 & $0.911^{* *}$ & $0.789^{* *}$ & 0.232 \\
$\begin{array}{l}\text { Leaders in } \\
\text { voluntary org. }\end{array}$ & 0.154 & 0.193 & $0.474^{* *}$ & 0.136 \\
$\begin{array}{l}\text { Leaders in research } \\
\text { institutes and } \\
\text { universities }\end{array}$ & 0.052 & 0.286 & $0.506^{* *}$ & 0.010 \\
$\begin{array}{l}\text { Leaders in police } \\
\text { and courts of }\end{array}$ & 0.019 & 0.320 & $1.112^{* *}$ & $-0.346^{*}$ \\
justice & & & & \\
$\begin{array}{l}\text { Leaders in the } \\
\text { military services }\end{array}$ & 0.329 & $0.489^{* *}$ & 0.099 & 0.171 \\
$\begin{array}{l}\text { Politicians } \\
\text { ntrolled for age, edu- }\end{array}$ & Yes & Yes & $0.773^{* *}$ & \\
ion and gender & 0.05 & 0.08 & 0.13 & 0.06 \\
adjusted & 1386 & 1388 & 1488 & 1490 \\
\hline
\end{tabular}

** Significant at the 1 per cent level. ${ }^{*}$ Significant at the 5 per cent level.

Source: The Norwegian Leadership Study 2000. 


\section{Table 3}

The individual top leaders' trust in other institutions. Regression analyses (OLS). Non-standardized estimates

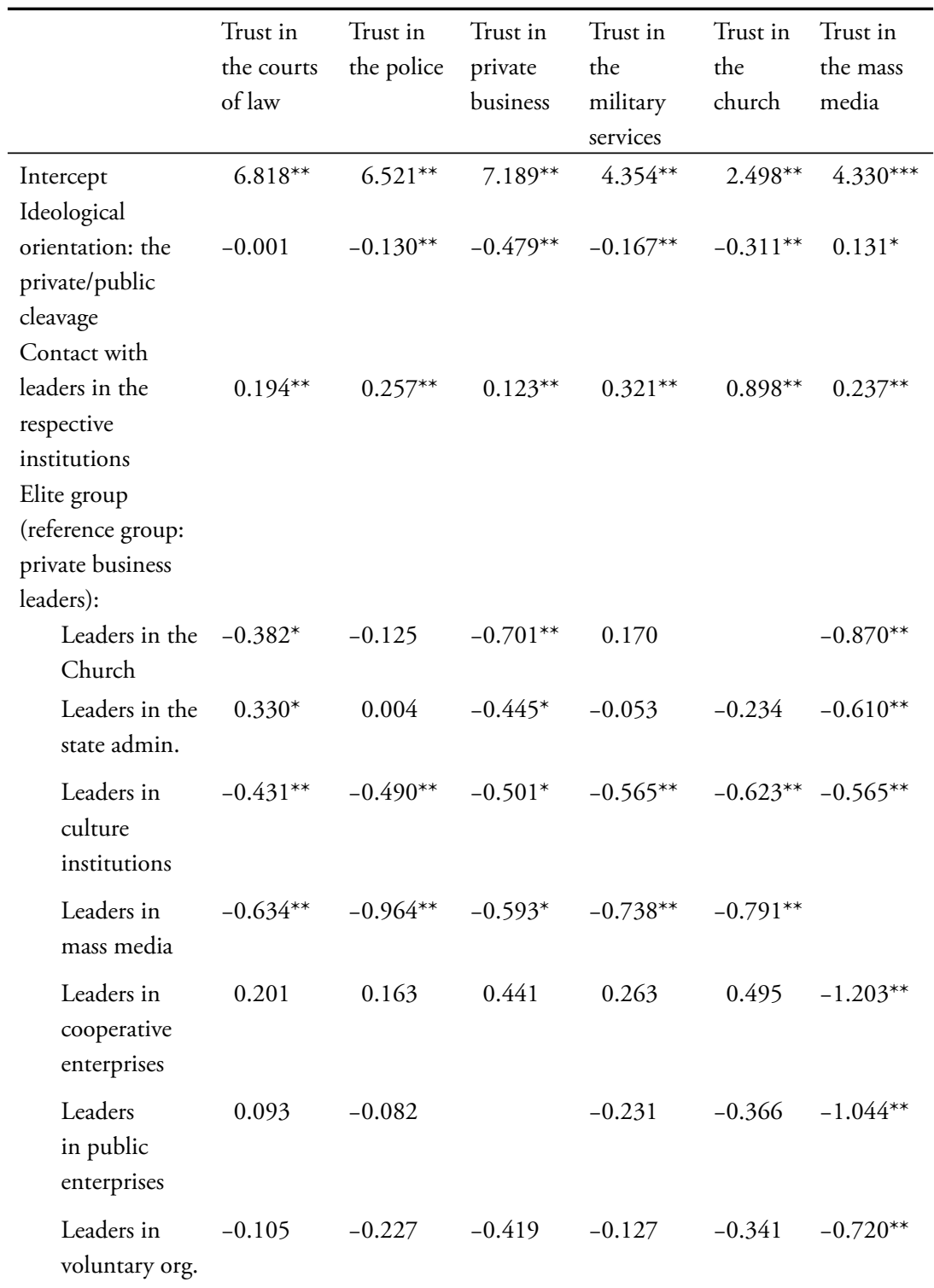


Table 3 (cont.)

\begin{tabular}{|c|c|c|c|c|c|c|}
\hline & $\begin{array}{l}\text { Trust in } \\
\text { the courts } \\
\text { of law }\end{array}$ & $\begin{array}{l}\text { Trust in } \\
\text { the police }\end{array}$ & $\begin{array}{l}\text { Trust in } \\
\text { private } \\
\text { business }\end{array}$ & $\begin{array}{l}\text { Trust in } \\
\text { the } \\
\text { military } \\
\text { services }\end{array}$ & $\begin{array}{l}\text { Trust in } \\
\text { the } \\
\text { church }\end{array}$ & $\begin{array}{l}\text { Trust in } \\
\text { the mass } \\
\text { media }\end{array}$ \\
\hline $\begin{array}{l}\text { Leaders in } \\
\text { research } \\
\text { institutes and } \\
\text { universities }\end{array}$ & -0.059 & 0.243 & $0.440^{* *}$ & $-0.193^{*}$ & $-0.758^{* *}$ & $-0.838^{* *}$ \\
\hline $\begin{array}{l}\text { Leaders in } \\
\text { police and } \\
\text { courts of } \\
\text { justice }\end{array}$ & & & $-0.655^{* *}$ & $0.357^{*}$ & 0.408 & $-1.041^{* *}$ \\
\hline $\begin{array}{l}\text { Leaders in the } \\
\text { military } \\
\text { services }\end{array}$ & 0.082 & $0.441^{*}$ & -0.321 & & 0.069 & $-0.469^{*}$ \\
\hline Politicians & 0.218 & 0.234 & -0.211 & $0.529^{* *}$ & 0.308 & $-0.834^{* *}$ \\
\hline $\begin{array}{l}\text { Controlled for } \\
\text { age, education } \\
\text { and gender }\end{array}$ & Yes & Yes & Yes & Yes & Yes & Yes \\
\hline R2 adjusted & 0.06 & 0.08 & 0.12 & 0.06 & 0.15 & 0.05 \\
\hline $\mathrm{N}$ & 1544 & 1545 & 1380 & 1490 & 1555 & 1681 \\
\hline
\end{tabular}

** Significant at the 1 per cent level. * Significant at the 5 per cent level.

Source: The Norwegian Leadership Study 2000.

The findings presented in the two tables confirm first of all that variations in the top leaders' institutional trust are significantly related to the sector or institution to which they belong. This result supports the theoretical idea which was advocated above, that institutional affiliation significantly affects the attitudes, in this case the trust of the elite persons.

In the theory section I suggested that one mechanism by which institutional affiliation influence the top leaders' trust in other institutions is identification: the members of an elite group identify with other elite groups who have similar basic function as their own group. I hypothesized that this identification may promote trust in the institutions concerned. In line with this hypothesis Table 2 demonstrates that when controlling for ideological orientation the top civil servants have more trust in the 
Storting, the Cabinet and the political parties than the other elite groups. Their trust is not then not due to any ideological sympathy with the political party holding power at the time of the interviews. ${ }^{8}$ Similarly, the members of military elite have significantly more trust in the police, also an order elite group, than the other elite groups; and on their part the police leaders and judges have high trust in the military services.

The preceding interpretations are, however, somewhat weakened by the fact that the political elite has no more trust in the public administration than the other elite groups, and the military elite has no more trust in the courts of justice than the other elites.

Tables 2 and 3 indicate that other aspects of the elite groups' functions also affect their trust evaluations. As shown in Table 1 also, the mass media and the culture elites in particular have significantly lower trust in the police, the military services and the private business, even when controlled for their ideological orientation and their frequency of contact with the institutions. The idea elites are also negative in their evaluation of the trustworthiness of the church. As indicated above, these findings probably reflect the role as critical institutions which the mass media and the culture occupy.

Secondly, and as expected, institutional trust is also significantly related to the ideological orientation of the groups' members. The more the members of an elite group support the present welfare state model of Norway, the more trust they have in the public administration and the less trust in private business and in the church. On the other hand, this finding implies that the stronger the opposition by an elite person to the state model, the less trust its members have in the public administration and the more trust in private business (and the church).

Above, I discussed whether the private business leaders' lower confidence in the political institutions, relatively to the other elite groups, might be a result of their negative ideological attitudes towards the public sector. In order to follow up this idea I have carried out a separate set of analyses (not reported here) checking whether the effect on political trust of belonging to the business elite group is affected by introducing the business leaders'

8) Unfortunately we cannot control for the frequency of contact with members of the Cabinet and the Storting, cf. note 6. The analysis of the trust of the senior state officials in the political parties is, however, controlled for the frequency of contact with top leaders in the political parties. 
individual ideological views. The results of the analyses confirm that the business leaders' trust towards the political institutions to some extent is explained by their more conservative ideological attitudes. However, even when controlling for ideological outlook there remains a significant (negative) statistical relationship between being a member of the business elite and trust in the Storting, the Cabinet and the public administration compared to being a member of some of the other elite groups. Their relatively lower trust in these institutions is then not only a result of their ideological stance, but is probably related also to other aspects of the business elite's culture and world views.

Within the research on citizens' confidence in the political institutions it has been discussed whether their attitudes are influence by how satisfied they are with the economic and political performance of the government (McAllister 1999; Miller and Listhaug 1999). In line with this discussion it is possible that the private business leaders' more sceptical attitude towards the political institutions is caused by a discontent with the concrete public benefits accruing to themselves. I have attempted to follow up this idea using data from the Leadership on the top leaders' lobby activities. They were asked whether (and how) they last year had attempted to influence the outcome of a political decision which was vital to their organization or company. They were also requested to report whether they were satisfied with the outcome of their lobby actions. I have carried out separate analyses (not reported here) where I have related the business leader' political trust to their evaluation of the result of the lobbying. It appeared to be no significant relationship between these two variables, indicating that the business leaders' trust attitudes are not primarily based upon their perceptions of any positive or negative outcome of relating directly to the political system.

It is surprising that the elite groups which are the most eager proponents of the welfare state accord the church less trust than other elite groups. The relatively negative evaluation of the church expressed by these elite groups may be a reaction to the conservative role that the church traditionally used to have in the Norwegian society and the conservative attitudes which previously prevailed within the church. But this situation implies that the elite groups which are sceptical to the church have failed to notice the changes of mentality and ideology that have been going on within the church. They have missed the fact that the top leaders in the church today appear as one of the most radical elite groups in the Norwegian society. 
The tables also offer evidence for the linkage between the frequency of contact that elite persons have with top leaders in another institution and their trust in this institution, i.e. top leaders who see each other frequently develop more trust in each other's institutions than elite groups with less frequent contact.

The politicians emerged as an elite group which exhibit slightly more general institutional trust than the other elite groups. The difference is, however, not significant. This finding is nonetheless interesting when related to some other results from the Leadership study. In another paper I have reported that the members of the politic elite are less apprehended of populism and political indifference among the voters, and they report less frequently worries about too weak political parties and the power of the government (Gulbrandsen 2005c). Both this more "laid-back" attitude and their general institutional trust are consistent with studies of politicians' tolerance (Sullivan et al.1993) and with theories of political socialization (Sullivan et al 1993; Searing 1986). Several studies have documented that politicians are more tolerant for instance towards extremist groups than the general public. To a certain extent this has been explained by selective recruitment. Individuals recruited to politics have psychological and social properties which foster greater tolerance. As Sullivan et al. (1993) have demonstrated, this is not a sufficient explanation. They claim that the tolerance of the politicians also is a result of the gradual political socialization of political recruits before they enter the main positions in the political system. Politicians are exposed to more ideological variation and learn the necessity of political compromise both of which instil in them a more realistic and less dramatic image of the potential threats of nonconformist groups and their ideas. The experience of having to take political responsibility and consider the consequences of ones actions inhibits them from intolerance of others. Moreover, central politicians acquire a sense of personal control which also may be favourable to the development of political tolerance.

These mechanisms of political socialization may also explain why Norwegian politicians more frequently have trust in the main institutions in the society and a more relaxed view upon populism and voter indifference. 


\section{Summary and Conclusions}

Elites in a modern democracy are to a large extent elected and employed leaders of large institutions and organizations. They are expected to represent and take care of the interests of the principals of their respective institutions and organizations. Living up to this responsibility necessitates that the members of the individual elite groups cooperate, negotiate and enter into compromises with the representatives of the other elite groups in society. In previous elite research it has been claimed that this kind of elite accommodation is facilitated to the extent that the various elites are integrated. In this paper I have argued that trust is an important characteristic of such elite integration.

Following up this theoretical idea I have set out to examine the extent to which important elite groups in the Norwegian society have trust in each other's institutions. I have also attempted to discuss how variations in institutional trust between the various elite groups and their members can be explained.

The analyses presented above have demonstrated that the general level of institutional trust is about the same in the different elite groups. Nonetheless, the elites appeared as less enthusiastic about the trustworthiness of the Norwegian institutions than expected.

There are, however, interesting variations as to how much trust the individual elite groups accord the various institutions. The top leaders within private business elite stand out with less trust in the political institutions than the other elite groups. At the same time private business as an institution is given relatively low trust by the other elite groups. The church leaders have less trust in private business than all the other national leaders. The top civil servants distinguish themselves by having more trust in the political institutions compared to the other elites. The two order elites, the top officers in the military services and the top leaders within the police, have more trust in each other's institutions than the rest of the elite groups. Top leaders within the mass media and the cultural sector for their part emerged as being particularly sceptical towards the order institutions and the church.

The analyses indicate that top leaders' evaluation of trust is affected by the extent of which they identify with the functions of the individual institutions. To a certain extent the patterns of trust between elite groups and institutions are attributable to the ideological orientation of the members of the various elite groups and to their contact with the institutions concerned. 
The distrust expressed by the mass media and culture elites, particularly in the order institutions, cannot however, be explained by any of these three factors. Their distrust illustrates that the elites' institutional trust may be significantly affected by basic orientations and responsibilities which are specific for the particular institutions and which are not necessarily influenced by the private attitudes, characteristics and experiences of the individual leaders.

Against the background of the business leaders' right wing ideological orientation, I had expected that they also distinguished themselves as less integrated in the trust structure than the other elite groups. Admittedly, private business receives relatively little trust from the other elites groups, and the business leaders on their part express less trust in the Cabinet and public administration than the other top leaders. The differences are, however, modest. This finding is in contrast to what Vogel (1978) some years ago observed in USA. Vogel described the private business leaders as an elite group which had very little faith in the state and the public sector. Accordingly, the Norwegian business leaders seem to be less in an "outsider" position concerning institutional trust than their colleagues in USA.

The mass media are characterized by receiving distinctly lower trust than other institutions. This situation should not, however, be seen as an evidence of the mass media elite being an outcast among the national elites in Norway. The low trust which the mass media is accorded is probably caused by a discontent on the part of these elites both with the pressing and critical scrutiny of the mass media and with their power to direct the political agenda. Nonetheless, there is a general recognition of the basic role and function of the mass media. The mass media as an institution is thus well integrated into the Norwegian society.

The relatively low standing of the mass media within the "trust structure" may illustrate a more general idea within the elite theory. Both Raymond Aron (1968) and Schmuel N. Eisenstadt (1966) have emphasized that democracy is dependent upon a balance between elite unity and elite independence. To Aron, an integrated elite would end freedom, while a fragmented elite would undermine the state. Similarly, Eisenstadt claimed that the success of democracy rested on two seemingly contradictory conditions: a differentiation between the elites which could open up for competition between alternative power centres, and a consensus between the elites about the basic values and rules of the game. From such a perspective 
the independent and critical role of the mass media is a significant prerequisite for democracy, even if it is accompanied by low trust shown by the other elite groups in society.

\section{References}

Aardal, B. 2003. "Kritiske velgere." Chapter 9 in Velgere i villrede. En analyse av stortingsvalget $i$ 2001, edited by B. Aardal. Oslo: Damm forlag.

Aron, R. 1968. Progress and Disillusion. London: Pall Mall.

Baier, A. 1986. "Trust and Antitrust." Ethics 96:231-260.

Blau, P. 1964. Exchange and Power in Social Life. New York: Wiley.

Bürklin, W., H. Rebenstorf et al. 1997. Eliten in Deutschland. Opladen: Leske+Budrich.

Coleman, J. 1990. Foundations of Social Theory. Chapters 5 and 8. Cambridge, MA: The Belknap Press of Harvard University Press.

Delhey, J. and K. Newton 2005. "Predicting Cross-National Levels of Social Trust: Global Patterns or Nordic Exceptionalism?” European Sociological Review 21:311-327.

Deutsch, M. 1962. "Cooperation and Trust: Some Theoretical Notes." In Nebraska Symposium on Motivation, edited by M.R. Jones. Lincoln: University of Nebraska Press.

Domhoff, G. 1967. Who Rules America? Englewood Cliffs, NJ: Prentice-Hall

Eisenstadt, S.N. 1966. Modernization: Protest and Change. Englewood Cliffs, NJ: Prentice Hall.

Gulbrandsen, T. 2005a. "Norway; Trust Among Elites in a Corporatist Democracy." Comparative Sociology 4:115-135.

. 2005b. "Ideological Integration and Variation within the Private Business Elite in Norway." European Sociological Review 21:329-344.

_ - 2005c. "An Elitist Norwegian Elite? Elite Perceptions of Challenges to Democracy in Norway." Paper presented at an international conference on elite research in, Balestrand, Norway, June 9-12.

Gulbrandsen, T., F. Engelstad, T.B. Klausen, H. Skjeie, M. Teigen and Ø. Østerud 2002. Norke makteliter (Norwegian Power Elites). Oslo: Gyldendal akademisk.

Higley, J. and M.G. Burton 1989. "The Elite Variable in Democratic Transitions and Breakdowns." American Sociological Review 54:17-32.

- 2006, Elite Foundations of Liberal Democracy. Oxford: Rowman \& Littlefield Publishers, Inc.

Higley, J. and G. Moore 1981. "Elite Integration in the United States and Australia." The American Political Science Review 75:581-597.

Higley, J., U. Hoffmann-Lange, C. Kadushin and G. Moore 1991. "Elite Integration in Stable Democracies: A Reconsideration." European Sociological Review 7:35-53.

Hoffmann-Lange, U. 1985. "Structural Prerequisites of Elite Integration in the Federal Republic of Germany." Research in Politics and Society 1:45-96.

Kadushin, C. 1995. "Friendship among the French Financial Elite." American Sociological Review 60:202-221.

Lijphart, A 1969a. The Politics of Accomodation. Berkeley: University of California Press. 
1969b. "Consociational democracy." World Politics 21:207-225.

Listhaug, O. and M. Wiberg 1995. "Confidence in Political and Private Institutions." In Citizens and the State, edited by H.D. Klingemann and D. Fuchs. Oxford: Oxford University Press.

McAllister, I. 1999. “The Economic Performance of Governments." In Critical Citizens. Global Support for Democratic Governance, edited by P. Norris. Oxford: Oxford University Press.

Miller, A. and O. Listhaug 1999. "Political Performance and Institutional Trust." In Critical Citizens. Global Support for Democratic Governance, edited by P. Norris. Oxford: Oxford University Press.

Mills, C. Wright 1956. The Power Elite. Oxford: Oxford University Press.

Mosca, G. 1939. The Ruling Class. New York: McGraw-Hill.

Offe, C. 1999. "How Can We Trust Our Fellow Citizens?” In Democracy and Trust, edited by P. Warren. Cambridge: Cambridge University Press.

Parry, G. 1976. "Trust, Distrust and Consensus." British Journal of Political Science 6:129-142.

Porter, J. 1965. The Vertical Mosaic. An Analysis of Social Class and Power in Canada. Toronto: University of Toronto Press.

Presthus, R. 1973. Elite Accomodation in Canadian Politics. Toronto: McMillan.

Putnam, R.D. 1976. The Comparative Study of Political Elites. Englewood Cliffs, NJ: Prentice-Hall.

Rokeach, M., P. W. Smith and R.I. Evans 1960. "Two Kinds of Prejudice or One?" Pp. 132-168 in The Open and the Closed Mind: Investigations into the Nature of Belief Systems and Personality Systems, edited by M. Rokeach. New York: Basic Books.

Searing, D.D. 1986. "A Theory of Political Socialization: Institutional Support and Deradicalization in Britain." British Journal of Political Science 16:341-376.

Sejersted, F. 1993. Demokratisk kapitalisme. Oslo: Universitetsforlaget.

Strømsnes, K. 2003, Folkets makt. Medborgerskap, demokrati og deltakelse. Oslo: Gyldendal Akademisk.

Sullivan, J.L., P. Walsh, M. Shamir, D.G. Barnum and J.l. Gibson 1993. "Why Politicians Are More Tolerant: Selective Recruitment and Socialization among Political Elites in Britain, Israel, New Zealand and the United States." British Journal of Political Science 23:51-76.

Sztompka, P. 1999. Trust. A Sociological Theory. Cambridge: Cambridge University Press. Vogel, D. 1978. "Why Businessmen Distrust Their State: The Political Consciousness of Corporate Executives." British Journal of Political Science 8:45-78. 